\title{
Potency of Antigenic and Serologic Tests Based on CNTKCQTP Linear Epitope on H5N1 Haemagglutinin for Avian Influenza
}

\author{
Tarigan S, Sumarningsih \\ Indonesian Research Center for Veterinary Sciences \\ E-mail:simsont@me.com \\ (received 18-11-2015; revised 23-02-2016; 03-03-2016)
}

\begin{abstract}
ABSTRAK
Tarigan S, Sumarningsih. 2016. Potensi tes antigen dan tes serologi yang didasarkan pada epitope linier CNTKCQTP pada haemagglutinin H5N1 untuk Avian Influenza. JITV 21(1): 62-72. DOI: http://dx.doi.org/10.14334/jitv.v21i1.1251

Alat diagnosa cepat atau point-of-care (POC) test sangat dibutuhkan dalam usaha pengendalian dan pemberantasan high pathogenic avian influenza (HPAI) H5N1 di Indonesia. Akurasi alat diagnosa POC ditentukan oleh spesifitas antibodi yang merupakan komponen utama dari semua alat diagnosis cepat. Baru-baru ini dilaporkan bahwa epitop CNTKCQTP yang terletak pada residu asam amino 274-281 protein hemaglutinin H5 hanya dimiliki oleh virus H5N1 dan semua clade virus subtipe H5N1 memiliki epitop tersebut. Penelitian ini bertujuan memproduksi dan mengevaluasi spesifitas poliklonal antibodi terhadap epitope tersebut. Antibodi diproduksi dengan cara mengimunisasi kambing dengan peptida tersebut dalam bentuk multiple antigen peptide (MAP). Spesifitas antibodi diukur dengan cara menganalisis reaktivitasnya terhadap virus influenza subtipe H3N3, H4N4, H5N1, H6N5, H7N7, H9N2, H10N7 dan H11N9, dan rekombinan hemagglutinin H1-H12, H14 dan H15 dengan ELISA dan immunoblot. Hasil ELISA dan immunoblot menunjukkan bahwa antibodi CNTKCQTP tidak spesifik terhadap haemagglitinin H5 karena memiliki reaksi silang dengan haemgglutinin lain terutama H7, H8 dan H9. Potensi peptida yang mengandung epitop, GNCNTKCQTPMGAINSS. sebagai reagen ELISA untuk mengukur antibodi H5 pada ayam yang sebelumnya telah divaksin dan ditantang dengan virus H5N1 juga dievaluasi dalam penelitian ini. Berbeda dengan hasil peneliti sebelumnya, ELISA yang menggunakan peptida tersebut sebagai coating atau pelapis tidak sensitif mendeteksi antibody haemagglutinin $\mathrm{H} 5$ pada ayam.
\end{abstract}

Kata Kunci: Virus AI, Hemagglutinin H5, Epitop CNTKCQTP, MAP, Immunoassay

\begin{abstract}
Tarigan S, Sumarningsih. 2016. Potency of antigenic and serologic tests based on CNTKCQTP linear epitope on H5N1 haemagglutinin for Avian Influenza. JITV 21(1): 62-72. DOI: http://dx.doi.org/10.14334/jitv.v21i1.1251

Rapid diagnostic tools or point-of-care (POC) test is needed in the effort to control and eradicate the high pathogenic avian influenza (HPAI) H5N1 in Indonesia. Accuracy of a POC test is determined by the specificity of antibodies, which is the main component of a POC test. Recently a linear epitope, CNTCKQTP epitope, located at 274-281 amino acid residue of H5 hemagglutinin has been confirmed to be present all clade of H5N1 viruses. This study aimed at producing and evaluating the reactivity of a monospecific, polyclonal antibody against the epitope. The Antibody was produced by immunizing a goat with the peptide in the form of multiple antigen peptide (MAP). The specificity of the antibody was estimated by assaying its reactivity against influenza virus subtypes H3N3, H4N4, H5N1, H6N5, H7N7, H9N2, H10N7 and H11N9; and recombinant hemagglutinins $\mathrm{H} 1-\mathrm{H} 12, \mathrm{H} 14$ and $\mathrm{H} 15$ with ELISA and immunoblot. The results of the assay showed that CNTKCQTP antibody was not specific for $\mathrm{H} 5$ haemagglitinin because it cross-reacted with other haemagglutinins especially $\mathrm{H} 7, \mathrm{H} 8$ and $\mathrm{H} 9$. The potential of the peptide containing the epitope, GNCNTKCQTPMGAINSS. as an ELISA reagent for assaying H5 antibodies in chickens previously vaccinated and challenged with the H5N1 virus was also evaluated in this study. In contrast the results of previous studies, the ELISA using GNCNTKCQTPMGAINSS as coating antigen was not sensitive in detecting antibody to haemagglutinin $\mathrm{H} 5$ in chickens.
\end{abstract}

Key Words: AI Virus, Hemagglutinin H5, CNTKCQTP Epitope, MAP, Immunoassay

\section{INTRODUCTION}

In the early 2000s, highly pathogenic avian influenza (HPAI) H5N1 influenza was detected in many parts of the world causing concerns particularly after eighteen people were hospitalized, six of whom died, after contracting the H5N1 virus from infected chickens (Claas et al. 1998). Between December 2003 and
January 2004, outbreaks of H5N1 sprang up simultaneously in eight countries in the East and Southeast Asia (Sims et al. 2005). Within three years, the disease has spread to 63 countries (FAO 2012) and caused death and culling of about 400 million domestic poultry globally with estimated economic losses of about US \$20 billion (FAO 2012). Most of the 63 affected countries were able to eliminate H5N1 virus 
rapidly except for China, Indonesia, Vietnam, India, Bangladesh and Egypt, where eradication of the disease proven to be difficult and subsequently has become endemic (FAO 2011).

One of the most important factors for those countries that successfully eradicated $\mathrm{H} 5 \mathrm{~N} 1$ virus was their ability to quickly recognise the disease enabling rapid elimination of all infected birds. To be able to recognize a disease quickly, the availability of appropriate diagnostic techniques is of paramount importance. For countries where the $\mathrm{H} 5 \mathrm{~N} 1$ has became endemic, two types of diagnostic tests are necessary; the first type that includes virus isolation and real time PCR, is intended for confirmatory, unambiguous diagnosis, whereas the second type is the point-of-care, or pen-site test intended for rapid diagnosis and to guide in determining actions needed to be taken for control or eradication of disease (Tarigan 2015). Most tests of the second type are immunological test based on the use of an antibody to detect the presence of H5N1 antigen.

To obtain an immunological test with high specificity, the use of monoclonal antibody is the preferred choice (Ho et al. 2009; Lin et al. 2015). However, production of suitable monoclonal antibody is expensive and requires high technical skills.

On the other hand however, the specificity, which is the main advantage of monoclonal antibody, may in some circumstances become a disadvantage. A monoclonal antibody may be so specific that it could not tolerate even a minute change (single amino acid change) in its epitope and this reduces its sensitivity when used in a diagnostic test (Khan 2014; Singh et al. 2014). Thus, in some instances a polyclonal antibody is more suited than a monoclonal antibody, especially when the polyclonal antibody has been generated against a small, unique antigen.

Recently, a linear epitope at amino acid residues 274-281 (CNTKCQTP) in the in HA1 region of the haemagglutinin specific for the H5N1 subtype viruses has been identified (Prabakaran et al. 2009). The epitope was shown to be $100 \%$ conserved among 163 human isolate and $96.9 \%$ in 906 avian isolate of H5N1 viruses. This epitope is not present in $\mathrm{H} 2, \mathrm{H} 3, \mathrm{H} 4$ and H6 - H16 subtypes of influenza viruses, or that the same sequence is present only in a small number $(2.3 \%)$ of H1 subtype strains. The CNTKCQTP epitope, in the form of a synthetic peptide, immobilized on a microtitre-plate reacted in ELISA with sera from birds vaccinated with different clades of $\mathrm{H} 5 \mathrm{~N} 1$ viruses (Velumani et al. 2011). The ELISA was reported to be $100 \%$ specific and recommended to be use as a tool in surveillance of $\mathrm{H} 5 \mathrm{~N} 1$ influenza in human and animals (Velumani et al. 2011).

The fact that the CNTKCQTP epitope is specific for the haemagglutinin of $\mathrm{H} 5 \mathrm{~N} 1$ viruses leads us to assumption that an antibody raised to that epitope may be useful as a diagnostic reagent in particular for pensite test intended for rapid H5N1 diagnosis in poultry. In this study we generated an antibody by immunizing a goat with a synthetic peptide CNTKCQTP and analyzed its reactivity against haemagglutinins of different subtypes of avian influenza viruses. The ultimate goal of this study was to evaluate the potency of the goatanti- CNTKCQTP epitope as the main reagent for immunodiagnostic test for H5N1 avian influenza.

\section{MATERIAL AND METHODS}

\section{Peptide}

Two forms of CNTKCQTP peptide were used in this study. The first was as a multiple antigenic peptide (MAP), a four-symmetrical-branched, 8-amino-acid (aa)-long (CNTKCQTP) peptide with unknown purity. This aa sequence is found in the haemagglutinin of all H5N1 viruses at aa position 274-281 (Prabakaran et al. 2009; Velumani et al. 2011). The second form was as a single linear 17-aa-long (GNCNTKCQTPMGAINSS) peptide with $>95 \%$ purity. This aa sequence is found in the haemagglutinin of all $\mathrm{H} 5 \mathrm{~N} 1$ viruses, at aa position 272-288 (Prabakaran et al. 2009; Velumani et al. 2011). Both peptides were synthetised by VCPBIO Ltd. Shenzhen City, China.

\section{Production and measurement of anti-CNTKCQTP- antibody}

A one year old, Ettawah-cross breed, male goat was purchased from a nearby farm. The goat was kept in a stilted, slitter floor isolated from other animal species, fed on natural foliage and grass supplemented with commercial concentrate $(0.1 \mathrm{~kg} /$ day $)$. After adapting to the laboratory condition for 3 weeks, the goat was immunized subcutaneously with $2 \mathrm{mg}$ CNTKQTP MAP in complete Freund's adjuvant. Booster Immunisations was carried out at 4 and 8 weeks after the first immunization with the same amount of peptide but with incomplete Freund's adjuvant. The fourth immunization was carried out 12 week after the first immunization with $4 \mathrm{mg}$ CNTKQTP MAP and Quil A adjuvant (Superfos Biosector, Denmark) intramuscularly. The goat was bled before each vaccination. Two weeks after the last immunization, the goat was humanely exsanguinated. Serum was aliquoted in $10 \mathrm{ml}$ tubes and stored at $-20^{\circ} \mathrm{C}$.

The level of anti-CNTKCQTP antibody in the serum of the goat before and after immunizations was measured with an indirect ELISA. The CNTKQTP MAP or GNCNTKCQTPMGAINSS single peptide was first diluted in $0.1 \mathrm{M}$ carbonate-bicarbonate buffer $(\mathrm{pH}$ 9.6) at $5 \mu \mathrm{g} / \mathrm{ml}$. Microtitre plates (Nunc Maxisorp ${ }^{\mathrm{R}}$ ) 
were coated with the peptide at $100 \mu \mathrm{l} /$ well at $4^{\circ} \mathrm{C}$ overnight. After blocking with non-fat skim milk (5 $\mathrm{mg} / \mathrm{ml}$ ) for 2 hours, serially diluted goat serum in PBS containing normal rabbit serum $(20 \mu \mathrm{l} / \mathrm{ml})$ was added and incubated at room temperature $\left(25^{\circ} \mathrm{C}\right)$ for $2 \mathrm{hrs}$. After washing four times with PBST $(0.05 \%$ Tween-20 in PBS, pH 7.2), rabbit- anti-goat-IgG- HRP conjugate (Sigma Co. Singapore), diluted in PBS-NRS at 1:4000, was added. After washing four times with PBST, solution of ABTS [2,2'-azino-bis(3ethylbenzothiazoline-6-sulphonic acid) and $\mathrm{H}_{2} \mathrm{O}_{2}$ substrate was added and the absorbance $\left(\mathrm{A}_{420}\right)$ measured with a microtitre-plate reader.

\section{Measurement of antibody level to CNTKCQTP in naïve, vaccinated and challenged chickens}

\section{Sera}

Sera from naïve, vaccinated and $\mathrm{H} 5 \mathrm{~N} 1$ infected chickens were obtained from an experiment conducted in our Laboratory and described previous (TARIGAN et $a l ., 2015)$. Briefly, layer chickens were vaccinated with a commercial-killed-H5N1 vaccine (Medivac-AI ${ }^{\circledR}, \mathrm{PT}$ Medion, Bandung, Indonesia). Two weeks after the last vaccination, birds were challenged with an isolate of H5N1 virus (A/Chicken/WestJava/Sbg-29/2007). Birds were bled one day before vacciation, two week after the first, second and third vaccination, and every week, from 1 to 8 weeks, after challenge. For the current study, 20 randomly selected sera were used from each, prevaccination (naïve sera), after $1^{\text {st }}, 2^{\text {nd }}$ and $3^{\text {rd }}$ vaccination (vacinated sera), one week after $\mathrm{H} 5 \mathrm{~N} 1$ challenge (early stage infection sera), 2- or 3- weeks after challenge (mid stage of infection sera) and $>4$ week after infection (late stage of infection sera). In addition, sera from two specific pathogen-free (SPF) chicken were also included in the assays (PT Vaksindo Satwa Nusantara, Indonesia).

\section{Measurement of antibody level to CNTKCQTP}

Antibody to CNTKCQTP in the bird's sera was measured by an indirect ELISA. Microtitre plate was coated with CNTKQTP MAP or GNCNTKCQTPMGAINSS single peptide and blocked as described previously for the immunized-goat sera. Bird's sera diluted 1: 100 were added to the plates and incubated for 2 hours. After washings four times with PBST, rabbit-anti-chicken IgG- HRP- conjugate (Sigma Co. Singapore) diluted at 1:5000 in PBST was added, then incubated at $37^{\circ} \mathrm{C}$ for 2 hours. In addition to the sera from the experimental birds, serum from SPF chickens were also added to the plates, as additional negative control. After washings, solution of substrate and chromogenic ABTS was added and the absorbance $\left(\mathrm{A}_{420}\right)$ meassured with a microtitre plate reader.

\section{Immunoblotting}

Immunoblot assay was used to analyse the reactivity of the CNTKQTP- goat antiserum with the different sub-types avian influenza viruses. The first immunoblot was between the serum and proteins of whole avian influenza viruses. The avian influenza virus subtypes available for this study included: (1) A/Avian/669/WA/78 (H3N8), (2) A/Grey Teal/WA/1840 (H4N4) (3) A/Chicken/WestJava/Sbg29/2007(H5N1), (4) (A/Shearwater/Australia/1/72 (H6N5), (5) A/Duck/Victoria/76/Keysborough (H7N7), (6) A/Turkey/Wisconsin/66 (H9N2), (7) CSIRO, AAHL GI (H10N7), (8) A/Tern/Aust/75 (H11N9). All viruses had been inactivated as they were prepared and used in haemagglutination inhibition (HI) test. All viruses, except for the $\mathrm{H} 5 \mathrm{~N} 1$ subtype viruses, were a kind gift from Dr. Peter Durr (Australian Animal Health Laboratory, Geelong, Australia). Before loading to the SDS-PAGE, the inactivated viruses were treated according to a previous method (ROSENBERG, 1996b). Briefly, $400 \mu \mathrm{l}$ methanol was added to $100 \mu \mathrm{l}$ virus suspension, vortexed briefly and spun at $14000 \times \mathrm{x} G$ for 10 second in a microfuge. After adding $150 \mu \mathrm{l}$ chloroform, the samples were vortexed and spun at 14000 x $G$ for 10 seconds. After adding $300 \mu$ distilled $\mathrm{H} 2 \mathrm{O}$ and vortex, the samples were spun at $14000 \times G$ for 30 second. The liquid above the protein band at the interface between $\mathrm{H}_{2} \mathrm{O}$ and chloroform was discarded, and $300 \mu \mathrm{l}$ methanol was added. Protein was pelleted at $14000 \times \mathrm{G}$ for 60 second. The supernatant was discarded and the protein pellet was dissolved with 100 $\mu 1$ SDS PAGE sample buffer, heated in boilling water for 5 minutes and loaded into the SDS PAGE gel (15 $\mu \mathrm{l} / 5$-mm-wide well.).

The second immunoblot was between the CNTKQTP-immunised-goat serum and recombinant haemagglutinins of all known haemagglutinins H1-H12, H14 and H15. The recombinant heamagglutinins, which were expressed in mammalian cells were purchased from Sinobiologicals Inc. China (Table 1). Each recombinant haemagglutinin was dissolved in SDSPAGE sample buffer at $200 \mu \mathrm{g} / \mathrm{ml}$, heated in boiling water for 5 minutes and loaded into the SDS PAGE gels $5 \mu \mathrm{l} / 3.4-$ mm-wide well.

Protein samples were separated on $10 \%$ separating gels then transfered onto a nitrocellulose membrane. Reversible staining with Ponceau $S$ was carried out to confirm the successful transfer and to asses the amount of each haemagglutinin on the membrane (Rosenberg 1996a). After blocking with skimmed milk ( $5 \mathrm{mg} / \mathrm{ml}$ in what?, 2 hours), serum from the CNTKQTP-immunised goat diluted at 1 : 200 in PBS containing 5\% normal 
rabbit serum were added and incubated at $25^{\circ} \mathrm{C}$ for 2 hours. After washings four times with PBST, rabbitanti-goat-IgG- -HRP-conjugate (Sigma Co. Singapore) diluted at $1: 5000$ was added and incubated for 2 hrs. After washing four times, chromogenic DAB (3,3'diaminobenzidine tetrahydrochloride) substrate $\left(\mathrm{H}_{2} \mathrm{O}_{2}\right)$ was added to detect bound antibody.

\section{Sequence analysis}

The alignment of CNTKCQTP epitope with the amino acid sequence of haemagglutinins used in this study was analysed using a bioinformatics software, Genious (Biomatters Ltd, Auckland, New Zealand). The amino-acid sequences of the recombinant haemagglutinins were download from Genebank (NCBI) based on the accession number provided by the vendor (Sino Biological Inc.). The similarity or percent of identityof of the CNTKCQTP epitope to its analogue in each haemagglutinin was determined by the percentage of identical amino acid.

Table 1. Recombinant Haemagglutinin (HA) from Sinobiological Inc., China used in this study

\begin{tabular}{|c|c|c|c|c|}
\hline HA & Source of gene & Purity & $\begin{array}{l}\text { Mr on SDS- } \\
\text { PAGE/length }\end{array}$ & Catalog No. \\
\hline H1 & $\begin{array}{l}\text { HA1+HA2, } 2 \text { aa deletion, uncleaved) from } \\
\text { A/California/07/2009 (H1N1), }\end{array}$ & $>95 \%$ & $\begin{array}{l}75-85 \mathrm{kDa} \\
529 \text { aa }\end{array}$ & $11085-\mathrm{V} 08 \mathrm{H}$ \\
\hline $\mathrm{H} 2$ & HA1+HA2, uncleaved) from (A/Japan/305/1957(H2N2) & $>97 \%$ & $\begin{array}{l}75-85 \mathrm{kDa} \\
525 \mathrm{aa}\end{array}$ & 11088-V08H \\
\hline $\mathrm{H} 3$ & $\begin{array}{l}\text { Native, HA1+HA2, uncleaved) from } \\
\text { A/Brisbane/10/2007(H3N2) }\end{array}$ & $>97 \%$ & $\begin{array}{l}90-100 \mathrm{kDa} \\
531 \text { aа }\end{array}$ & $11056-\mathrm{V} 08 \mathrm{H}$ \\
\hline $\mathrm{H} 4$ & $\begin{array}{l}\text { HA1+HA2, uncleaved) from A/Swine/Ontario/01911- } \\
\text { 1/99(H4N6) }\end{array}$ & $>92 \%$ & $\begin{array}{l}65-75 \mathrm{kDa} \\
528 \mathrm{aa}\end{array}$ & $11706-\mathrm{V} 08 \mathrm{H}$ \\
\hline H5 & $\begin{array}{l}\text { cleavage site mutated (RESRRKKR } \rightarrow \text { TETR, HA1+HA2, } \\
\text { uncleaved) from A/Indonesia/5/2005(H1N1) }\end{array}$ & $>98 \%$ & $\begin{array}{l}70-80 \mathrm{kDa} \\
531 \text { aa }\end{array}$ & 11060-V08H1 \\
\hline H6 & $\begin{array}{l}\text { HA1+HA2, uncleaved) from A/northern } \\
\text { shoveler/California/HKWF115/2007(H6N1) }\end{array}$ & $>93 \%$ & $\begin{array}{c}65 \mathrm{KDa} / \\
529 \mathrm{aa}\end{array}$ & $11723-\mathrm{V} 08 \mathrm{H}$ \\
\hline H7 & Native, HA1+HA2) from A/Netherlands/219/03(H7N1) & $>87 \%$ & $\begin{array}{l}59 \mathrm{kDa} / \\
536 \mathrm{aa}\end{array}$ & 11082-V08B \\
\hline $\mathrm{H} 8$ & $\begin{array}{l}\text { HA1+HA2, uncleaved) from A/pintail } \\
\text { duck/Alberta/114/1979(H8N4) }\end{array}$ & $>95 \%$ & $\begin{array}{l}53.1 \mathrm{kDa} \\
529 \mathrm{aa}\end{array}$ & 11722-V08B \\
\hline H9 & $\begin{array}{l}\text { HA1+HA2, uncleaved) from } \\
\text { A/chicken/Korea/164/04(H9N8) }\end{array}$ & $>95 \%$ & $\begin{array}{l}58.2 \mathrm{kDa} / \\
523 \mathrm{aa}\end{array}$ & 40183-V08B \\
\hline $\mathrm{H} 10$ & $\begin{array}{l}\text { HA1+HA2, uncleaved) from A/duck/Hong } \\
\text { Kong/786/1979(H10N3) }\end{array}$ & $>95 \%$ & $\begin{array}{l}60-65 \mathrm{kDa} / \\
525 \mathrm{aa}\end{array}$ & 11693-V08H \\
\hline H11 & $\begin{array}{l}\text { HA1+HA2, uncleaved) from } \\
\text { (A/mallard/Alberta/294/1977(H11N9) }\end{array}$ & $>97 \%$ & $\begin{array}{l}65-70 \mathrm{kDa} / \\
528 \mathrm{aa}\end{array}$ & 11704-V08H \\
\hline H12 & $\begin{array}{l}\text { HA1+HA2, uncleaved) from A/green-winged } \\
\text { teal/ALB/199/1991(H12N5) }\end{array}$ & $>97 \%$ & $\begin{array}{l}80-90 \mathrm{kDa} / \\
527 \mathrm{aa}\end{array}$ & 11718-V08H \\
\hline H13 & $\begin{array}{l}\text { HA1+HA2, uncleaved) from A/black-headed gull/ } \\
\text { Netherlands/1/00 (H13N8) }\end{array}$ & $>95 \%$ & $\begin{array}{l}60-70 \mathrm{kDa} / \\
528 \mathrm{aa}\end{array}$ & 11721-V08H \\
\hline H15 & $\begin{array}{l}\text { HA1+HA2, uncleaved) from } \\
\text { A/duck/AUS/341/1983(H15N8) }\end{array}$ & $>97 \%$ & $\begin{array}{c}75 \mathrm{kDa} / \\
534 \mathrm{aa}\end{array}$ & $11720-\mathrm{V} 08 \mathrm{H}$ \\
\hline
\end{tabular}




\section{RESULTS AND DISCUSSIONS}

\section{Results}

\section{CNTKCQTP antibody}

The titre of antibody to CNTKCQTP epitope in sera before and after vaccination with CNTKCQTP MAP is presented in Figure 1. As shown in the Figure, no antibody was detected in sera before vaccination using either CNTKCQTP

$$
\text { MAP }
$$

GNCNTKCQTPMGAINSS single peptide as antigens. After four vaccinations the serum had a high titre of antibodies as it recognised the CNTKCQTP MAP at high $1: 125,600$ dilution. However, the titre with GNCNTKCQTPMGAINSS single peptide was much lower than the CNTKCQTP MAP. The serum could not recognize the single peptide at dilution higher than 1 : 400. This means that the titer against the MAP peptide were higher by $126600 / 400=314$ times compared to that of single peptides.

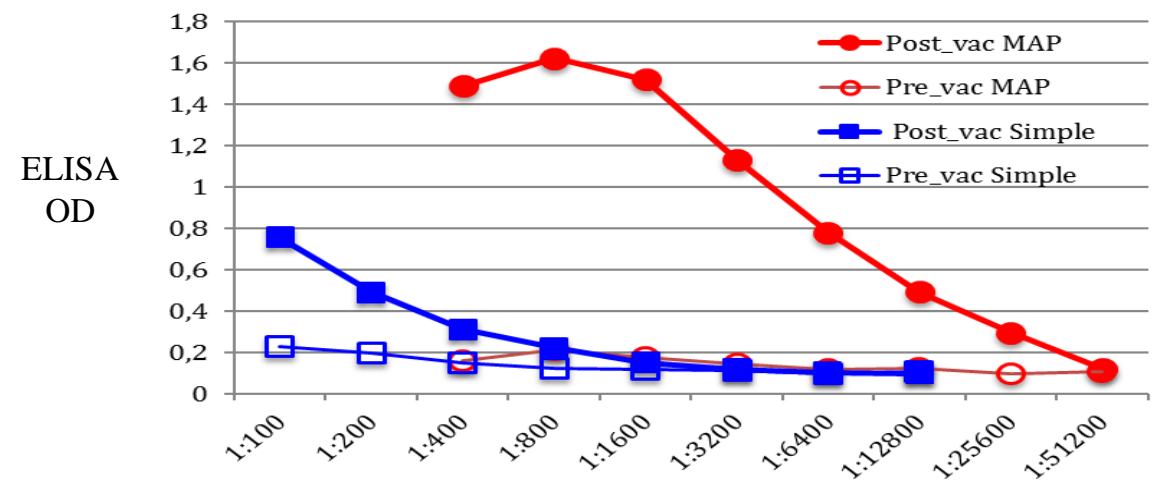

Serum Dilution

Figure 1. Antibody titre in CNTKCQTP MAP antiserum as detected in ELISA using the CNTKCQTP MAP (pre - and post- vac MAP) and GNCNTKCQTPMGAINSS single peptides (pre- and post-vac) as antigens.

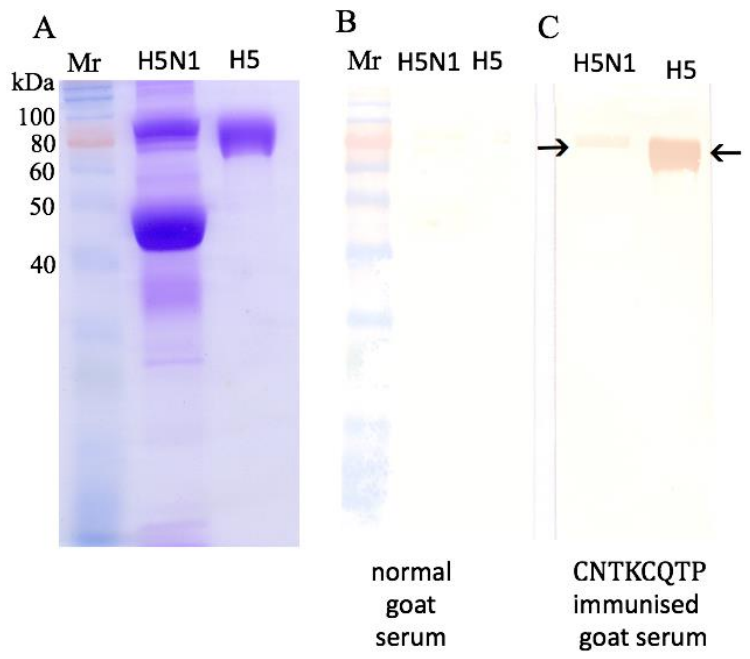

Figure 2. Reaction of CNTKCQTP MAP antisera with H5N1whole virus and recombinant H5 haemagglutinin protein in immunoblotting. H5N1whole virus proteins (H5N1) and recombinant H5 haemagglutinin (H5) separated on SDS-PAGE gel and (A) stained with Coomasie-blue. SDS-PAGE separated protein transferred to a nitrocellulose membrane and reacted with (B) normal, pre-immune goat serum (B) and (C) goat CNTKCQTP-MAP antiserum. Arrows = H5N1 haemagglutinin. 
A

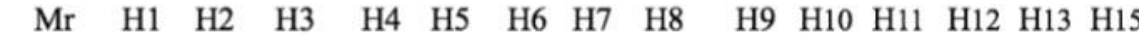

$\begin{array}{llllllllllllllll}\text { B } & \mathrm{Mr} & \mathrm{H} 1 & \mathrm{H} 2 & \mathrm{H} 3 & \mathrm{H} 4 & \mathrm{H} 5 & \mathrm{H} 6 & \mathrm{H} 7 & \mathrm{H} 8 & \mathrm{H} 9 & \mathrm{H} 10 & \mathrm{H} 11 & \mathrm{H} 12 & \mathrm{H} 13 & \mathrm{H} 15\end{array}$ 100 80 60 50

$\begin{array}{llllllllllllllllllllll}C & \mathrm{Mr} & \mathrm{H} 1 & \mathrm{H} 2 & \mathrm{H} 3 & \mathrm{H} 4 & \mathrm{H} 5 & \mathrm{H} 6 & \mathrm{H} 7 & \mathrm{H} 8 & \mathrm{H} 9 & \mathrm{H} 10 & \mathrm{H} 11 & \mathrm{H} 12 & \mathrm{H} 13 & \mathrm{H} 15\end{array}$ 100 80 60 50

$\Rightarrow$

\section{D}

$\begin{array}{lllllllllllllllllllllllll}\mathrm{H} 1 & \mathrm{H} 2 & \mathrm{H} 3 & \mathrm{H} 4 & \mathrm{H} 5 & \mathrm{H} 6 & \mathrm{H} 7 & \mathrm{H} 8 & \mathrm{H} 9 & \mathrm{H} 10 & \mathrm{H} 11 & \mathrm{H} 12 & \mathrm{H} 13 & \mathrm{H} 15\end{array}$

Figure 3. Reactivity of recombinant avian influenza haemagglutinins of different subtypes with serum from normal, non-immunised (B, D) and CNTKCQTP-MAP immunised goats (C). The amount of each recombinant haemagglutinin transferred onto the membrane was equal as shown by the intensity of Ponceau-stained band (A). 

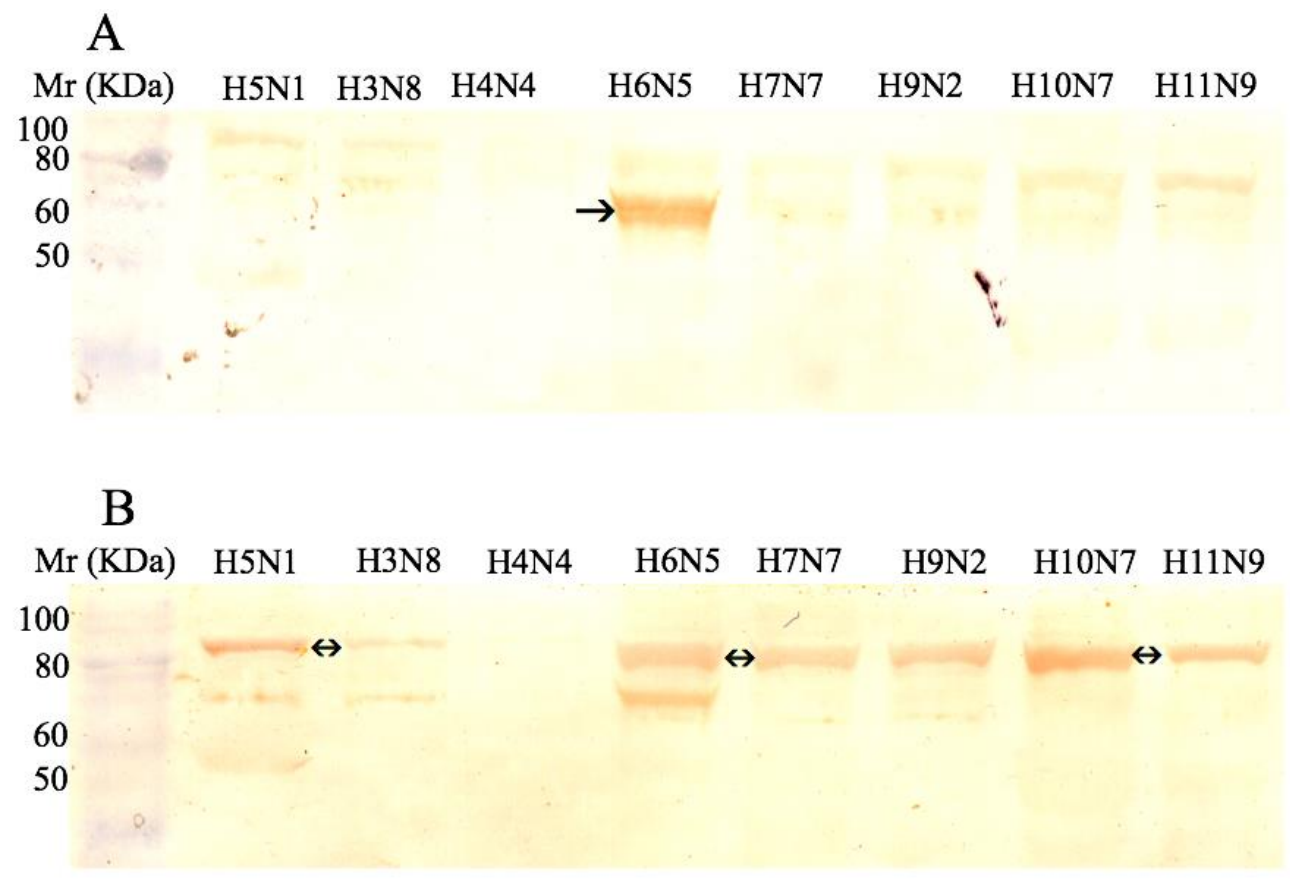

Figure 4. Reactivity of various subtypes of avian influenza virus proteins with sera from non-immune (A) and CNTKCQTP-MAP immunised goat (B). Notice that serum from non-immunised goat recognized strongly a protein band of H6N5 virus (arrow), the molecular weight of that protein was smaller than that of haemagglutinin (double head arrows).

The CNTKCQTP MAP antiserum recognised not only the peptide, but also recombinant haemagglutinin $\mathrm{H} 5$ and haemagglutinin protein from $\mathrm{H} 5 \mathrm{~N} 1$ virus. The antiserum recognized only one of the H5N1-virus proteins, which was supposedly haemagglutin because its molecular weight was similar to that of the recombinant $\mathrm{H} 5$. None of H5N1-virus proteins was recognised by the CNTKCQTP MAP antiserum (Figure 2C). Based on the thickness and stain intensity of immunoblot band, the recognition of the recombinant H5 protein by CNTKCQTP MAP antiserum was much stronger than that for H5N1-virus hemagglutinin. The differences could be attributed to the bigger amount of recombinant $\mathrm{H} 5$ than that of $\mathrm{H} 5 \mathrm{~N} 1$ haemagglutinin transferred onto the membrane (Figure 2A). The preimmune serum was negative for any antibody to H5N1virus as it did not recognized any of the H5N1virus proteins and the recombinant $\mathrm{H} 5$ proteins (Figure 2B).

The CNTKCQTP-MAP anti-serum recognized not only recombinant haemagglutinin $\mathrm{H} 5$, but also haemagglutinins $\mathrm{H} 7, \mathrm{H} 8, \mathrm{H} 9$, and to a lesser extend, H13 (Figure 3C). Serum from pre-immunised goat did not recognize haemagglutinin $\mathrm{H} 5$, but it recognised haemagglutinins $\mathrm{H} 4, \mathrm{H} 7, \mathrm{H} 8, \mathrm{H} 9$ and $\mathrm{H} 13$ (Figure 3B). Serum from a normal, non-vaccinated goat that had been kept frozen at $-20^{\circ}$ for five years, also recognized haemagglutinins H7, H8, and H9 (Figure 3D).
The negative results in the immunoblot assay was convincingly attributed to the absence of binding between haemagglutinin and specific antibody in the sera. It was not due to the absence or limited amount of haemagglutinin transferred onto the membrane. Based on the thickness of Ponceaou-stained bands, the amount of each haemagglutinin transfered onto the nitrocellulose membrane was more or less equal (Figure $3 \mathrm{~A})$. The purities of the recombinant haemagglutinins which were claimed by the vendor to be $>95 \%$ for most haemagglutinins, and the diversity of the molecular weights were approved by the Ponceaou-stained (Table 1).

When reacted with whole virus, the CNTKCQTPMAP antiserum recognized a protein from $\mathrm{H} 5 \mathrm{~N} 1$, H3N8, H6N5, H7N7, H9N2, H10N7 and H11N9. Protein in each virus subtype recognized by the antiserum has the same molecular weight, which was about $85 \mathrm{kDa}$. Serum from normal or preimmunised goat recognised a H6N6 protein band of MW which is of smaller size than expected MW of H6N5 haemagglutinin (Figure 4, arrow).

\section{Antibody to CNTKCQTP in chicken}

The presence or absence of antibody to CNTKCQTP epitope in H5N1 immune chicken sera is presented in Figure 5. The levels of exposure of 


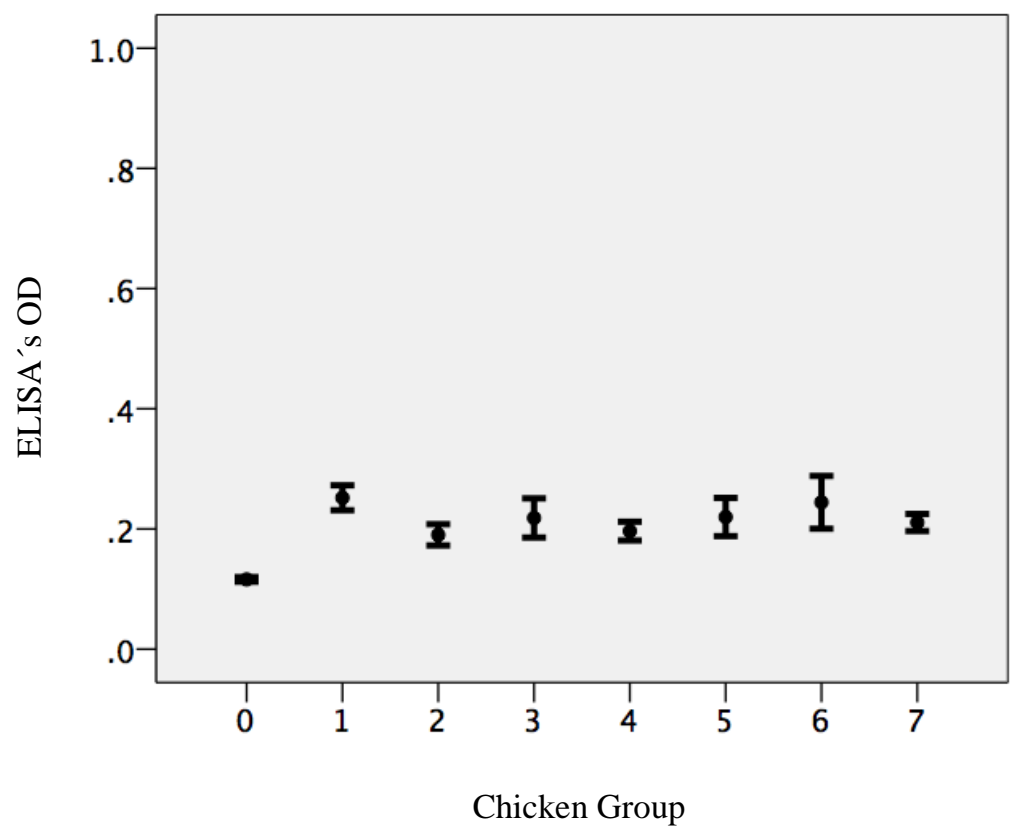

Figure 5. Antibody levels to CNTKCQTP-MAP in H5N1 immune chicken sera. $0=$ SPF (specific pathogen-free), $1=$ prevaccinated, $2=$ vaccinated once with killed AI vaccine $\left(\right.$ Medivac $\left.^{\mathrm{R}}\right), 3=$ vaccinated twice, $4=$ vaccinated three times, $5=$ vaccinated then challenged with $\mathrm{H} 5 \mathrm{~N} 1$ and sera collected $\leq 7$ dpi (day post infection), $6=$ vaccinated then challenged, sera collected 14-21 dpi, $7=$ vaccinated then challenged, sera collected $\geq 35$ dpi. Bars $=$ mean and $95 \%$ confidence interval of the means from 20 birds (groups 1-70, and from 3 birds (group 0).

Table 2. Alignment CNTKCQTP epitope with analogue epitopes in haemagglutinin

\begin{tabular}{cccccc}
\hline \hline $\begin{array}{c}\text { Haem- } \\
\text { agglutinin }\end{array}$ & Subtype & Gene Bank Acc No. & Amino acid sequence & Position & Identity $(\%)$ \\
\hline H1 & H1N1 & ACP44189.1 & CNTTCQTP & $292-299$ & 87.5 \\
H2 & H2N2 & AAA43185.1 & CETKCQTP & $288-295$ & 87.5 \\
H3 & H3N2 & ABW23353.1 & CNSECITP & $293-300$ & 62.5 \\
H4 & H4N6 & AAG17429.1 & CVSKCHTD & $291-298$ & 50 \\
H5 & H5N1 & ABW06108.1 & CNTKCQTP & $290-297$ & 100 \\
H6 & H6N1 & ACE81692.1 & CDATCQTI & $292-299$ & 50 \\
H7 & H7N7 & AAR02640.1 & CEGDCYHS & $293-300$ & 25 \\
H8 & H8N4 & AAG38554.1 & CNTKCQTY & $298-305$ & 87.5 \\
H9 & H9N8 & ABH12262.1 & CVVQCQTE & $286-293$ & 50 \\
H10 & H10N3 & BAF46762.1 & CESKCFWR & $287-294$ & 37.5 \\
H11 & H11N9 & ABB87228.1 & CSTKCQSE & $290-297$ & 62.5 \\
H12 & H12N5 & ABB88110.1 & CVTECQLN & $290-297$ & 50 \\
H13 & H13N8 & AAV91212.1 & CNTKCQTS & $290-297$ & 87.5 \\
H15 & H15N8 & ABB88132.1 & CEGECFYS & $296-303$ & 25 \\
\hline
\end{tabular}


chickens to $\mathrm{H} 5 \mathrm{~N} 1$ virus ranged from being anybody free as represented by SPF sera (group 0) to the those being exposed and represented by sera from chickens vaccinated multiple times and sera obtained following challenged with live H5N1 virus. The level of antibody to CNTKCQTP, as indicated by the ELISA's OD, in the SPF chicken was marginal lower compared to other groups. There were no differences in ODs between sera from pre-vaccinated (group 2) and post vaccinated birds (groups 2, 3, 4), and between pre-vaccinated (group 2) and post-challenged birds (groups 5, 6, 7). The low ELISA ODs indicated the absence of antibody to CNTKCQTP in all groups of the chicken.

\section{Amino-acid sequence alignment}

Alignment of CNTKCQTP epitope with analogue epitope in the amino acid sequence of haemagglutinins used in this study is presented in Table 2. Except for $\mathrm{H} 5$, none of the haemagglutinin had $100 \%$ similarity with the CNTKCQTP epitope. Four haemagglutinins (H1, H2, H8 and H13) had analogue epitopes with only one amino acid different with the CNTKCQTP epitope. The analogue epitope in the haemagglutinins $\mathrm{H} 7$ and H15, which had had only two identical amino acids, were the most divergent.

\section{Discussion}

This study shows that the linear CNTKCQTP epitope, which is located in the amino acid residue 274281 of H5N1 haemagglutinin is immunogenic as high antibody titre was obtained following immunization with the CNTKCQTP MAP. The goat-CNTKCQTPantisera would be useful as a reagent in the development of diagnostic test for $\mathrm{H} 5 \mathrm{~N} 1$ avian influenza because it recognized $\mathrm{H} 5 \mathrm{~N} 1$ haemagglutinin, either as a recombinant protein or as a native protein present in the $\mathrm{H} 5 \mathrm{~N} 1$ virus particle. The production of goat-CNTKCQTP-antisera was technically simple and inexpensive and this is important to overcome obstacles of using CNTKCQTP-monoclonal antibody that is expensive for routine diagnostic use (Velumani et al. 2011).

Interest in developing diagnostic tools for influenza has been great because the disease has been one of the most important diseases in human and animals. Pointof-care (POC) tests, most of which belong to the group of rapid immunological tests, have been the most widely developed tests because their benefits in the control of influenza either in animals or in human have been proven. In human, the ability to confirm that an illness is or is not caused by an influenza virus, using a POC test, can be a lifesaving undertaking because effective anti-influenza drugs are available (Gavin \& Thomson 2003). The importance of a POC test in the control measure of HPAI has been demonstrated in the PDSR (participatory Disease Survellance and Response) project, a successful HPAI control program in sector-4 poultry in Indonesia (Hawkes et al. 2014; Tarigan 2015).

The accuracy of an immunological test depends on the specificity of antibody used in the test. Being very specific, because it recognized only one epitope in the antigens, monoclonal antibodies have been used widely in the development of POC tests. For this reason, a large number of attempts have been made to produce monoclonal antibodies against influenza viruses (Wang et al. 2000; Rai et al. 2010; Wei et al. 2011; Bhat et al. 2013). Sometimes, however, a monoclonal antibody is too specific that it can not tolerate even a minor variation in its epitope, which reduce its diagnostic sensitivity when used in dignostic assay (Khan 2014; Singh et al. 2014).

The CNTKCQTP -polyclonal antibody produced in this study was also expected to be highly specific because its was produced against a short peptide expected to contain only a few antigenic epitopes. Additionaly polyclonal antibodies are considered to be more tolerant of antigenic variation in the epitope, and therefore when used in immunoassy, it should have higher sensitivity than monoclonal antibody.

As shown in this study, the polyclonal antibody no longer recognized the sequence (analogous epitope) even only one amino acid different, either the difference in the middle (haemagglutinins $\mathrm{H} 1$ and $\mathrm{H} 2$ ) or at the end of the sequence (haemagglutinins $\mathrm{H} 8$ and H13). This results may indicate that the CNTKCQTPMAP used to immunised the goat contains only a single epitope.

Previous study reported that monoclonal antibody to CNTKCQTP epitope, 5F8, had high specivicity (Prabakaran et al. 2009) and when used in an epitopeblocking ELISA against recombinat H5N1 haemagglutinin (HA0), the ELISA could identify specifically chicken that had been vaccinated against H5N1 virus and no cross reactions were observed with subtypes H1-H4, H6-H16 influenza viruses.

Unlike the 5F8-monoclonal antibody, the CNTKCQTP-MAP polyclonal antibody produced in this study was not specific for haemagglutinin of H5N1, because it also recognised haemagglutinin of other AIV subtypes, including H3N8, H4N4, H6N5, H7N7, H9N2, H10N7 and H11N9.

The use of recombinant haemagglutinins in immunoblot assay in the present study failed to establish the specificity of CNTKCQTP-MAP antiserum. This was because the goat used in the antibody production already had antibody to hemagglutinin of some isolates especially $\mathrm{H} 7, \mathrm{H} 8$ and $\mathrm{H} 9$ before immunisation. It is unknown how common it is normal or non-vaccinated goats being seropositive to 
H7, H8 and H9 haemagglutinins. However, the fact that serum from a non-immunised, heathy goat, collected five years ago, was also positive to those haemagglutinins when tested similarly may indicates that the condition is common. However, It is unknown whether the seropositivity was caused by infection with related subtypes of influenza-viruses or induced by other immunologically cross-reactive agents . The later possibility was more likely because it was supported by the results of other immunoblot assay using whole inactivated-influenza viruses in which the same nonvaccinated serum did not recognise haemagglutinin from $\mathrm{H} 7 \mathrm{~N} 7$ and H9N2 subtypes influenza viruses.

Before immunisation with the CNTKCQTP -MAP, the goat had been tested and it was seronegative to $\mathrm{H} 5 \mathrm{~N} 1$ virus. We did not, however, test the goat against hemagglutinin of other subtypes. In addition to our failure to envisage the possibility of the goat seropositive to haemagglutinin of other serotypes, the array of recombinant haemagglutins used in detection of the antibodies was not available untill the goat exsanguinated. This study, therefore, convinced the vital importance of testing animals to be used in the production of antiserum to be tested against haemagglutinin of subptypes all influenza virus before used.

The second aspect of the CNTKCQTP-peptide evaluated in this study, the use of the linear peptide in indirect ELISA to detect antibody, also generated results that are different to those of previous study (Velumani et al. 2011). In that study, the peptideELISA was able to specifically identify chicken that had been vaccinated with $\mathrm{H} 5 \mathrm{~N} 1$ virus of various clades. In the present study, on the other hand, a similar ELISA could not detect the present of specific antibody in chicken that had been vaccinated once, twice, thrice, or even in vaccinated chicken that had been challenged with a life $\mathrm{H} 5 \mathrm{~N} 1$ virus. There are three things that were different between ELISA in this study and that in previous study. First, the concentration of peptide used to coat the microtitre plate was $5 \mu \mathrm{g} / \mathrm{ml}$ in this study and $10 \mu \mathrm{g} / \mathrm{ml}$ in previous one. We are convinced that this concentration difference could not attributed to differences in the results because in our preliminary experiment, we found that no differences between both concentrations (data not presented). Second, in this study non-fat-skimmed milk was used as a blocking reagent whereas in previous study, bovine serum albumin was used. In our previous study, we found that non-fat-skimmed milk was effective as blocking agent and therefore the blocking reagent could not also be attributed to the differences result of this study and previous study (Tarigan et al. 2015). Third, in this study the chicken were immunised with a commercial H5N1 vaccine, whereas, in previous study the vaccine was prepared by the authors themselves. Because the vaccine was prepared by the authors themselves, the purity and the amount of immunogen contained in the vaccine were known with certainty. The purity and the amount of immunogen in the commercial vaccine in the present study were unknown.

In summary, immunisations of goat with the CNTKCQTP epitope, in the form of MAP, produced antibody that recognised $\mathrm{H} 5$ haemagglutinin but only $\mathrm{H} 5 \mathrm{~N} 1$ virus. The antibody is useful as the main reagent in development of rapid test for H5N1 avian influenza. Some apparently pre-immunised goats are seropostive for some influenza haemagglutinins, therefore testing goats against all influenza haemagglutinins before used for antibody production is vitally important. This study fail to demonstrate the presence of antibody to CNTKCQTP epitope in chicken that had been vaccinated or infected with $\mathrm{H} 5 \mathrm{~N} 1$ virus.

\section{CONCLUSION}

High titre antibody to CNTKCQTP epitope was produced by immunising goat with CNTKCQTP MAP. The serum recognised haemagglutinin $\mathrm{H} 5$ and therefore is useful as a reagent for detection of $\mathrm{H} 5 \mathrm{~N} 1$ virus. However, unlike CNTKCQTP monoclonal antibody generated previously, the serum is not specific for $\mathrm{H} 5 \mathrm{~N} 1$ haemagglutinin as it also recognises haemagglutinin of other influenza virus subtypes. Some apparently pre-immunised goats are seropostive for some influenza haemagglutinins, therefore testing goats against all influenza haemagglutinins before used for antibody production is vitally important. ELISA using peptide containing the epitope sequence, GNCNTKCQTPMGAINSS, cannot be used to detect anti-H5N1 antibody in chicken immunised with commercial-H5N1 vaccine.

\section{ACKNOWLEDGMENT}

Some apparently pre-immunised goats are seropostive for some influenza haemagglutinins, therefore testing goats against all influenza haemagglutinins before used for antibody production is vitally important.

This work was supported by the Australian Centre for International Agricultural Research under Grant AH/2010/039. The authors thank Mrs Gita Sekarmila, $\mathrm{Mr}$ Achpas and the animal caretakers for their excellent technical assistance.

\section{REFERENCES}

Bhat S, Bhatia S, Sood R, Bhatnagar H, Pateriya A, Venkatesh G. 2013. Production and characterization of monoclonal antibodies against nucleoprotein of avian 
influenza virus. Monoclon Antib Immunodiagn Immunother. 32:413-418.

Claas EC, de Jong JC, van Beek R, Rimmelzwaan GF, Osterhaus AD. 1998. Human influenza virus A/HongKong/156/97 (H5N1) infection. Vaccine. 16:977-978.

[FAO] Food and Agriculture Organization. 2011. Approaches to controlling, preventing and eliminating H5N1 Highly Pathogenic Avian Influenza in endemic countries. FAO Animal Production and Health Paper No. 171.

[FAO] Food and Agriculture Organization. 2012. H5N1 HPAI global overview, January-March 2012. Issue No. 31. [accessed April 16th 2015]. http://www.fao.org /docrep/015/an388e/an388e.pdf

Gavin PJ, Thomson RB. 2003. Review of rapid diagnostic tests for influenza. Clin Appl Immunol Rev. 4:151-172.

Hawkes P, Echalar R, Budiharta S, Soenarjo S. 2014. USAID/Indonesia Avian And Pandemic Influenza (API) program evaluation: 2009-2014. GH Tech Project Bridge IV, Report No. 14-B4-009.

Ho HT, Qian HL, He F, Meng T, Szyporta M, Prabhu N, Prabakaran M, Chan KP, Kwang J. 2009. Rapid detection of H5N1 subtype influenza viruses by antigen capture enzyme-linked immunosorbent assay using H5and N1-specific monoclonal antibodies. Clin Vaccine Immunol. 16:726-732.

Khan FH. 2014. Antibodies and their applications. In: Verma AS, Singh A, editors. Animal biotechnology-model in discovery and translation. Amsterdam (NL): Acad Press. p. 473-490.

Lin J, Wang R, Jiao P, Li Y, Li Y, Liao M, Yu Y, Wang M. 2015. An impedance immunosensor based on low-cost microelectrodes and specific monoclonal antibodies for rapid detection of avian influenza virus $\mathrm{H} 5 \mathrm{~N} 1$ in chicken swabs. Biosens Bioelectron. 67:546-552.

Prabakaran M, Ho HT, Prabhu N, Velumani S, Szyporta M, He F, Chan KP, Chen LM, Matsuoka Y, Donis RO, Kwang J. 2009. Development of epitope-blocking ELISA for universal detection of antibodies to human H5N1 influenza viruses. PLoS One. 4:e4566.

Rai M, Bhatia S, Malik YP, Dubey SC. 2010. Production and characterization of monoclonal antibodies against NS1 protein of $\mathrm{H} 5 \mathrm{~N} 1$ avian influenza virus. Hybridoma (Larchmt). 29:183-186.

Rosenberg IM. 1996a. Protein analysis and purification. benchtop techniques. Boston (USA): Birkshauser Boston. p. 158-159.

Rosenberg IM. 1996b. Protein analysis and purification. benchtop techniques. Boston (USA): Birkhauser Boston. p. 130.

Sims LD, Domenech J, Benigno C, Kahn S, Kamata A, Lubroth J, Martin V, Roeder P. 2005. Origin and evolution of highly pathogenic H5N1 avian influenza in Asia. Vet Rec. 157:159-164.

Singh A, Chaudhry S, Agarwal A, Verma AS. 2014. Antibodies: Monoclonal and Polyclonal. In: Verma AS, Singh A, editors. Animal biotechnology-model in discovery and translation. Amsterdam (NL): Acad Press. p. 265-287.

Tarigan S. 2016. Peranan Point-of-Care-Test dalam pengendalian High Pathogenic Avian Influenza di Indonesia. Wartazoa. 26:39-50.

Tarigan S, Indriani R, Durr PA, Ignjatovic J. 2015. Characterization of the M2e antibody response following highly pathogenic $\mathrm{H} 5 \mathrm{~N} 1$ avian influenza virus infection and reliability of M2e ELISA for identifying infected among vaccinated chickens. Avian Pathol. 44:259-268

Velumani S, Ho HT, He F, Musthaq S, Prabakaran M, Kwang J. 2011. A novel peptide ELISA for universal detection of antibodies to human H5N1 influenza viruses. PLoS One. 6:e20737.

Wang X, Castro AE, Castro MD, Lu H, Weinstock D, Soyster N, Scheuchenzuber W, Perdue M. 2000. Production and evaluation criteria of specific monoclonal antibodies to the hemagglutinin of the $\mathrm{H} 7 \mathrm{~N} 2$ subtype of avian influenza virus. J Vet Diagn Invest. 12:503-509.

Wei J, Yan B, Chen Z, Li T, Deng F, Wang H, Hu Z. 2011. Production and characterization of monoclonal antibodies against the hemagglutinin of $\mathrm{H} 5 \mathrm{~N} 1$ and antigenic investigation of avian influenza $\mathrm{H} 5 \mathrm{~N} 1$ viruses isolated from China. Can J Microbiol. 57:42-48. 